Iranian Journal of Breast

Diseases. 2022; 14(1):36-48.
Original Article

\section{Women's Lived Experiences of Femininity after Mastectomy and Treatment: A Qualitative Study}

\author{
Ghazafari A ${ }^{1}$, Nikoogoftar $\mathbf{M}^{2 *}$ \\ ${ }^{1}$ Department of Sociology, Islamic Azad University, Roodehen Branch, \\ Tehran, Iran \\ ${ }^{2}$ Department of Psychology, University of Payam Noor, Tehran, Iran
}

Receive: $12 / 1 / 2021$

Accepted: $23 / 3 / 2021$

"Corresponding Author: mnikoogoftar@gmail.com

Ethics Approval: IR.IAU.SRB.REC.1397.145

\begin{abstract}
Introduction: Breast cancer is the most prevalent cancer among women, and mastectomy, the surgical treatment for this cancer, affects different aspects of patients' life. This study aimed to describe women's lived experiences of femininity after mastectomy and treatment.

Methods: This qualitative study was conducted on 17 breast cancer survivors in Tehran in 2018-2019. The participants, who were selected through snowball sampling, had undergone mastectomy at least 6 months before and were younger than 50 years. Data were collected using in-depth semi-structured interviews and analyzed with the contractual content analysis method.
\end{abstract}

Results: The analysis of patients' experiences led to the identification of 7 main themes (and 18 subtheme): social life (social isolation, quitting the job or getting a part-time job, and dropping out of school), body image (being asymmetric, being unattractive, and requiring reconstructive surgery), others' opinions (complaining about how others look at them and concerns of being pitied), marital relationships (fear of abandonment, fear of spouse's pity, shame of being nude, and compromised sexual intimacy), reproductive health (premature menopause and possible infertility), perceived support (attending support group meetings and keeping in touch with cured ones), taking responsibilities of household works (inability to do housewife affairs and inability to do the housework).

Conclusion: Mastectomy and treatment for breast cancer greatly affect many areas of individual and social life and marital relationships of patients, necessitating the need to develop and establish free support resources by NGOs and highlighting the government's role in reducing the psychological and family damage caused by the disease.

Keywords: Breast Cancer, Mastectomy, Femininity, Snowball Sampling Method, Body Image 
مقاله بشروهشى تجربه زيسته زنان از زنانكى بعد از ماستكتومى و درمان؛ يك

آزاده غضنفرى'، منصوره نيكو گفتتار Гا"

ا كروه جامعهشناسى، دانشخاه آزاد اسلامى واحد رودهن، تهران، ايران

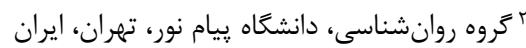

فصلنامه بيمارى هاى يستان ايران

$1 \varepsilon \cdot \because \mid \varepsilon(1):$ rา-EA
هـ

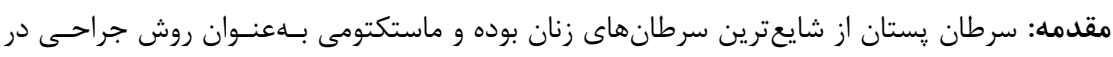

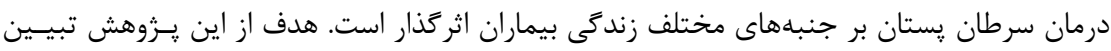

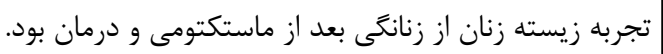
روش بررسى: اين مطالعه به روش كيفى بر روى IV نفر از بيماران ماستكتومى شـدهاى كـه حـداقل

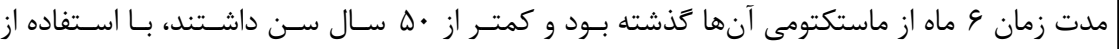

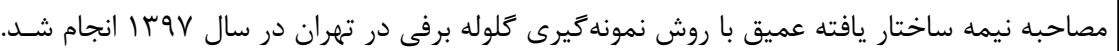

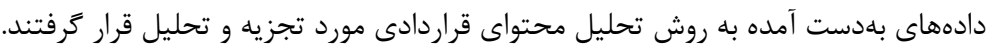

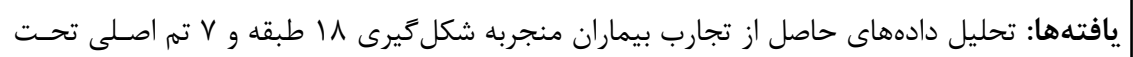

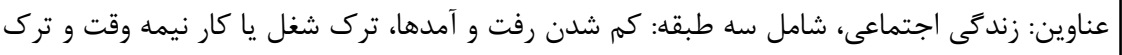

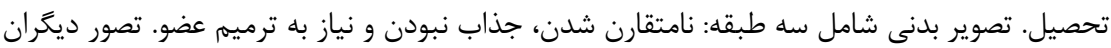

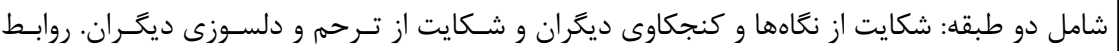

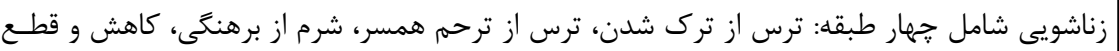

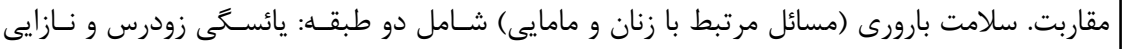

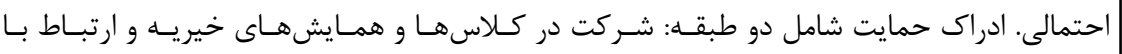

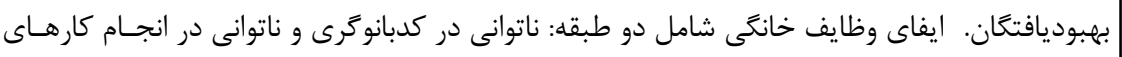
دستى خانكى. نتيجهديرى: بر اساس يافتههاى مطالعه حاضر مىتوان نتيجه گرفت ماستكتومى و درمان سرطان

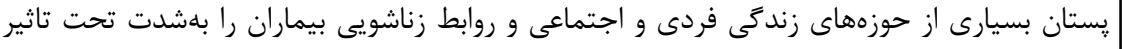

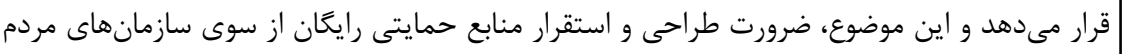

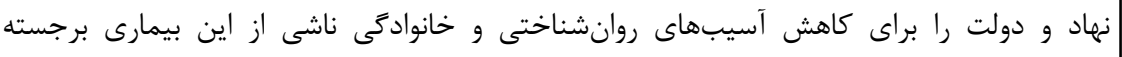
مى سازد. | وازههاى كليدى: سرطان بستان، ماستكتومى، زنانگى، روش نمونه گيرى گلوله برفى، تصوير بدنى

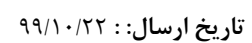

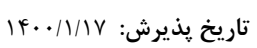

"نويسنده مسئول: mnikoogoftar@gmail.com 
ذهنى نيز متفاوت خواهند بود و به تبع آن از زنانكى

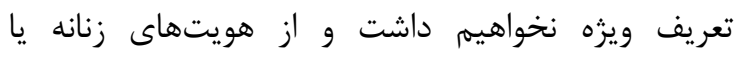
زنانكى ها صحبت به ميان خواهد آمد (؟).

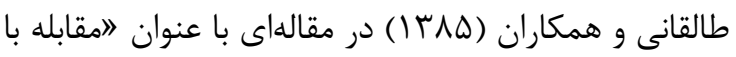

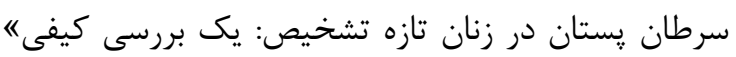

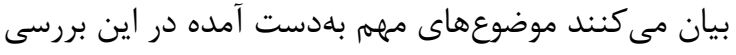

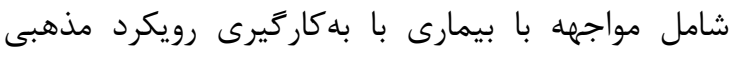
(تسليم به بيمارى بهعنوان يك تقديرالهى، استمداد مذهبى)، نكَرش نسبت به بيمارى (مثبتانديشى: اميد به

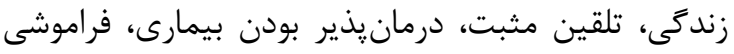

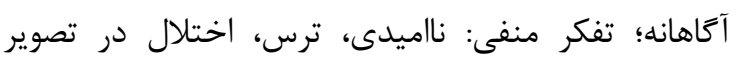
ذهنى)، يذيرش حقيقت بيمارى (يذيرش فعال: مبارزه با تاريا

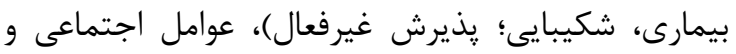

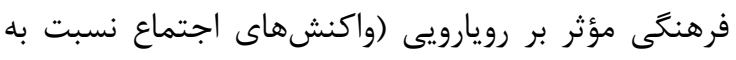

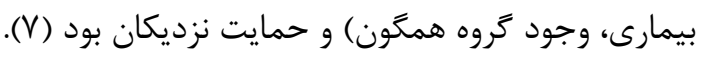

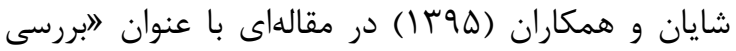

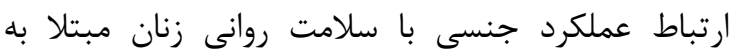

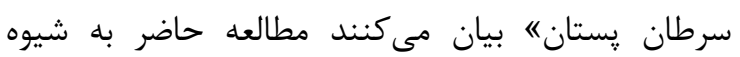
توصيفى- تحليلى از نوع مقطعى و با حجم نمونه معادل ץ.1 نفر به روش در دسترس، در زنان مبتلا به سرطان

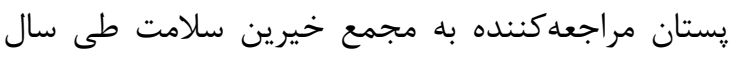

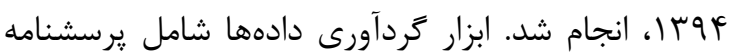

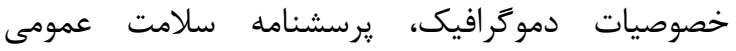

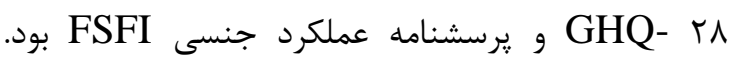

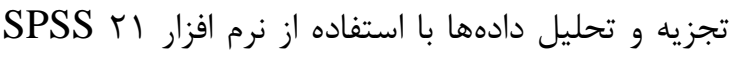

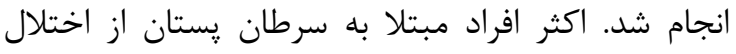

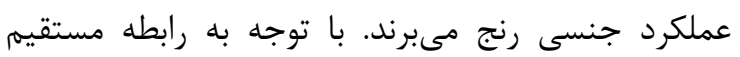

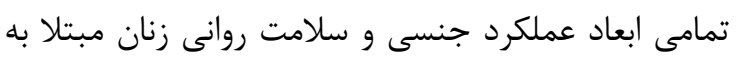
سرطان يستان، شناخت و آكاهى در زمينه تغييرات

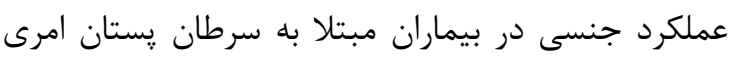

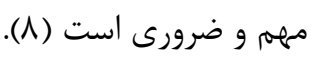

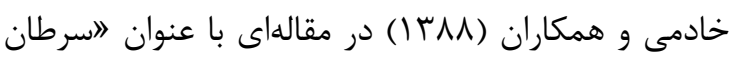

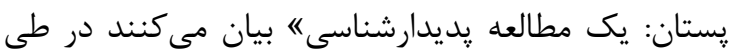

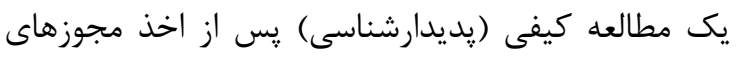

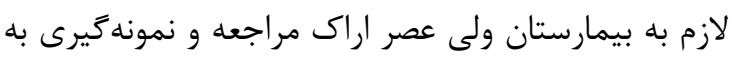
روش مبتنى بر هدف انجام شد و تا اشباع اطلاعات تعداد

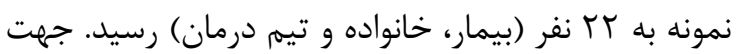

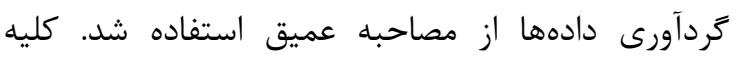

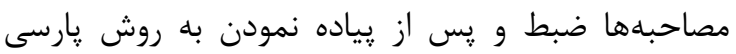

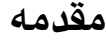

رشد روزافزون سرطان يستان در جند دهه اخير و اثرات

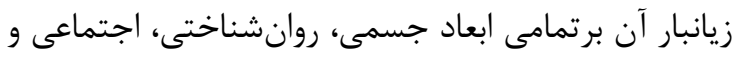

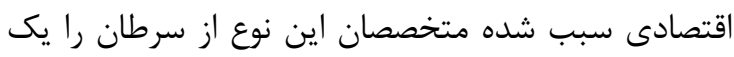
مشكل بهداشتى عمده قرن معرفى مى كنند. در ايران نيز

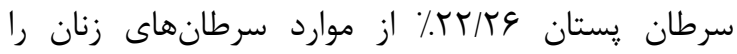

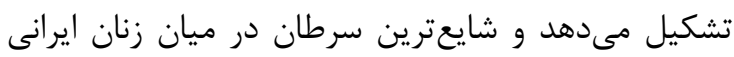

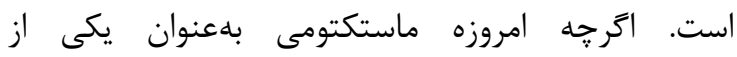

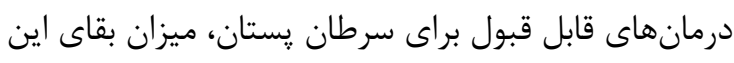

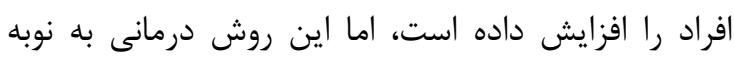

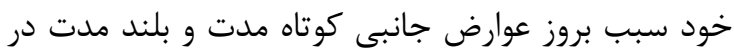

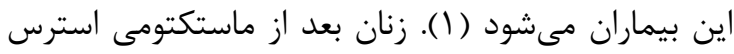

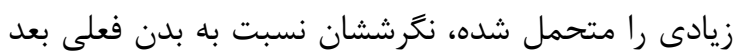

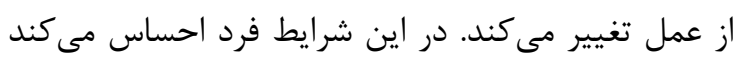

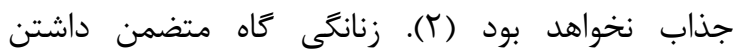

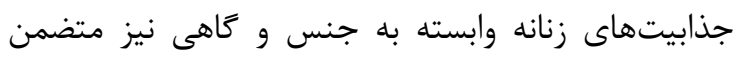

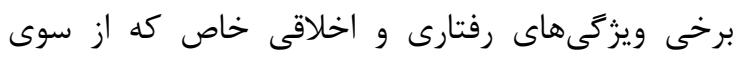

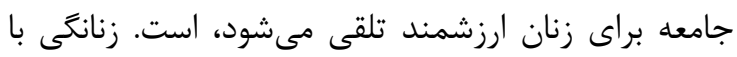

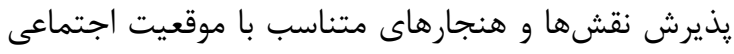

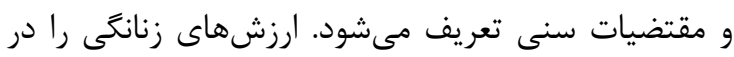

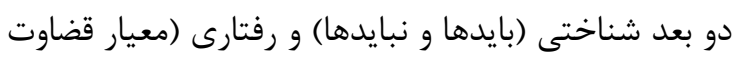

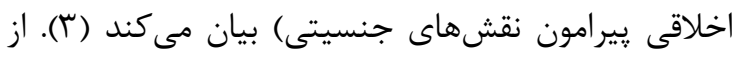

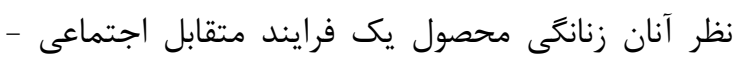
فرهنگیى و بيولوزيكى است كه نظامى از روابط اجتماعى باني هويت زنانه را بازنمايى مى كند. به عقيده كيدنز مراقبت از بدن يكى از ابز ابزارهاى اساسى

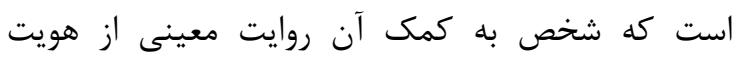

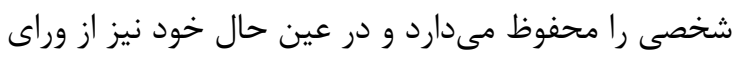

همين روايت در معرض تماشا و داورى قرار مى كيرد (أ).

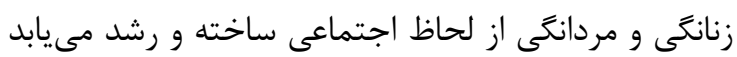

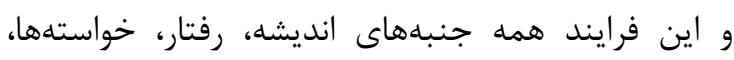

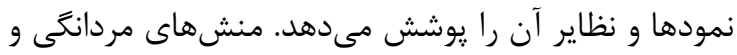
زنانكى توسط مردمى كه فرهنگ مشترك دارند توليد و

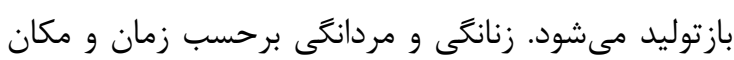

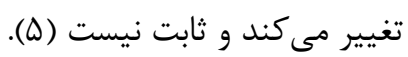
بدين نحو زنانكى در ارتباطى سهكانه ميان ذهنيت،

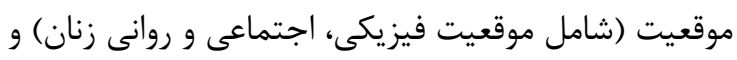

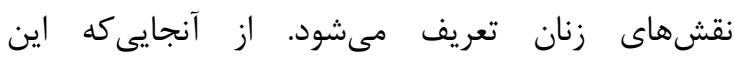
موقعيتهاى اجتماعى متفاوت هستند ساختمان هاى إن إنى 
سرطان يستان اين نتايج به دست آمد. يافتههاى تحقيق

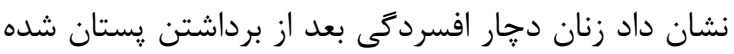

و به سختى با اين مشكل كنار آمدهاند (rآ)

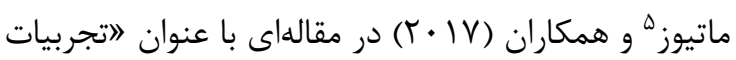

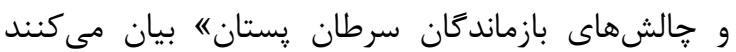

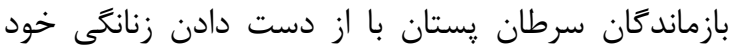

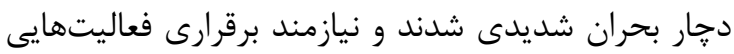

براى يذيرش اين هويت جديد بودهاند (f (l). يرداختن به مساله زنان هم موجب بسط شناخت زنانكى لنى

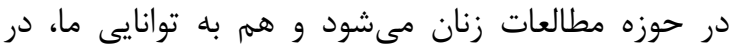
درى ماهيت زنانكى نزد زنان ماستكتومى شده و و تغييرات

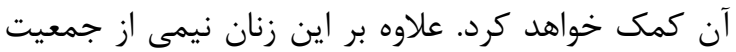

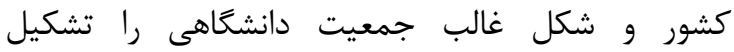

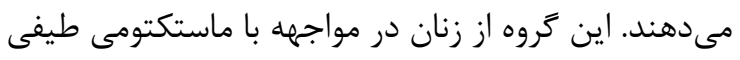

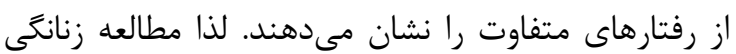
آنان در سيستم آكادمى ضرورى است و دريافتن ابعاد

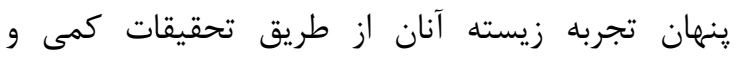

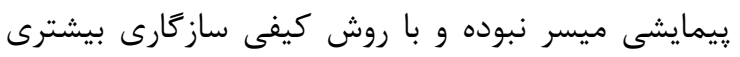

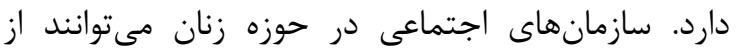
نتايج اين يزوهش در عرصه برنامهريزى و تصميمَيرى داري بهرهمند شوند. هدف از انجام اين مطالعه، بررسى تجرئ برديه

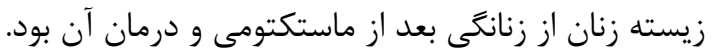

\section{مواد و روشها}

اين مطالعه با رويكرد كيفى و با روش تحليل محتواى

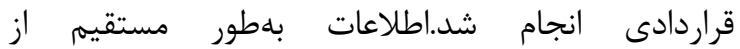
مشاركت كنند

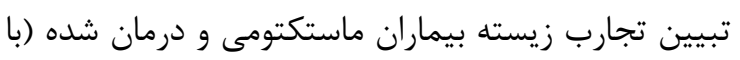

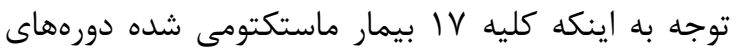
شيمىدرمانى و راديوترايى را كذراندهاند لذا اين متغيرها

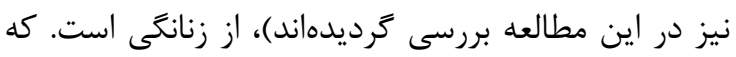

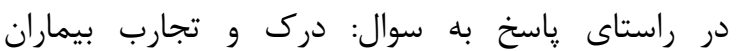

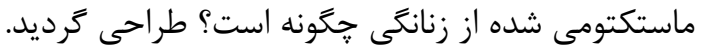

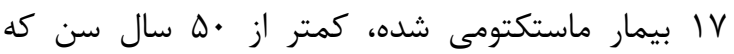

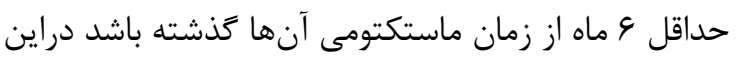
مطالعه شركت كردند. نمونه گيرى به صورت هدفمند و به إنها روش كلوله برفى انجام شد (اولين مصاحبه شونده از

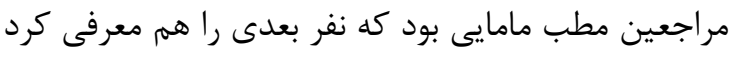

تفسير ترديد. در اين تحقيق تلاش شد تا براساس معيارهاى موثق بودن دادههاى كيفى و تجزيه و تحليل

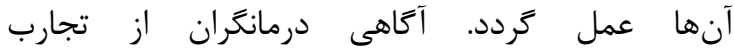

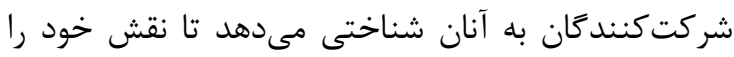

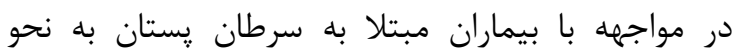
مناسبترى ايفا نمايند. اين يافتهها همجنين بر ضرورت بندان تغيير جهت از درمان انتهايى به تشخيص زودرس و

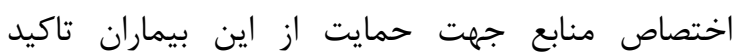

مىنمايند (9)

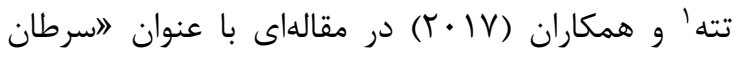
يستان و هويت، فرهنَ و جامعهله بيان مى كنند سرطان يستان در ميان زنان سفيد يوست شايع مىباشد. بان بان

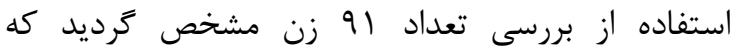

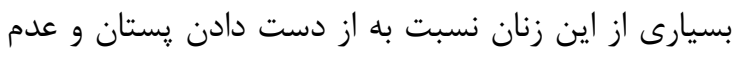

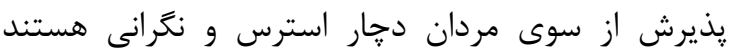

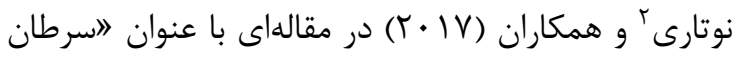

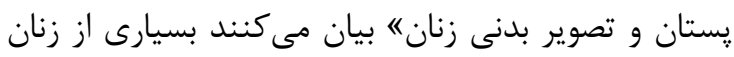

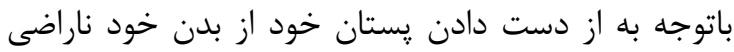

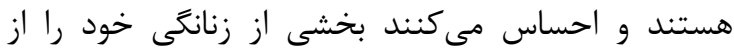

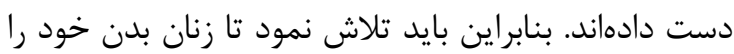
به درستى درك نمايند و بتوانند كيفيت زندگى خود را بالا

برند (1) - (1).

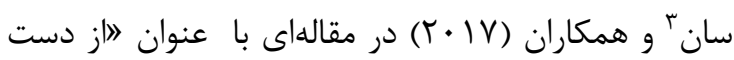

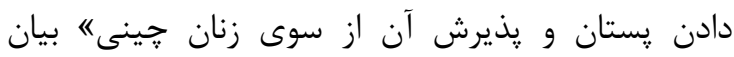

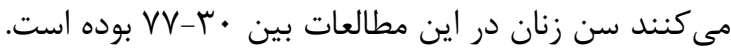
دو موضوع در اين مقاله مد نظر قرار كرفته است تغييرات

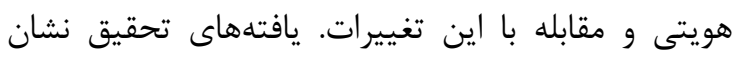
مى دهد زنان بازمانده از سرطان قُ يستان توانستند اين

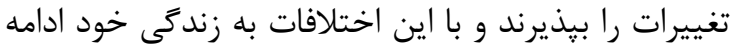

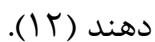

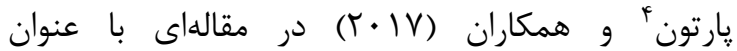
الجربيات زنان در مورد تغيير جنسيت در مسير بيمارى

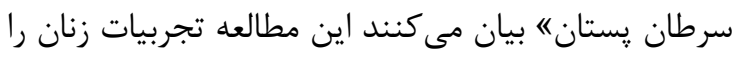
در ارتباط با سرطان يستان و تغييرات هويتى آنان را بيان

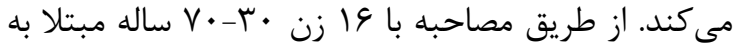

\footnotetext{
${ }^{1}$ Teteh

${ }^{2}$ Notari

${ }^{3}$ Sun

${ }^{4}$ Parton
} 
مصاحبه از سوى بيمار انجام مىشد. اماكن انجام مصاحبه

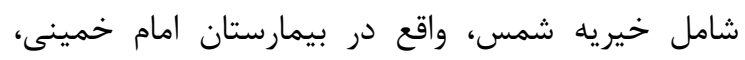

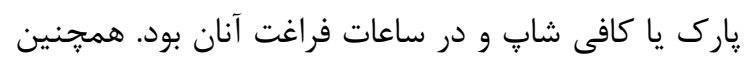
بهره خيرى از روش مطالعه مكرر، مقايسه مستمر دادهانها،

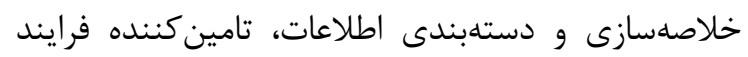

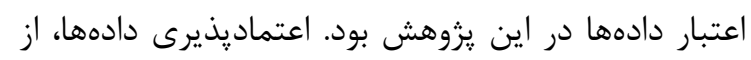

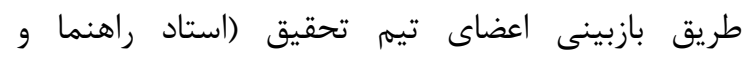

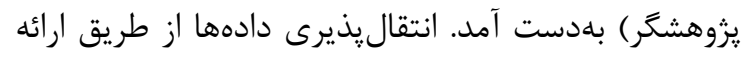

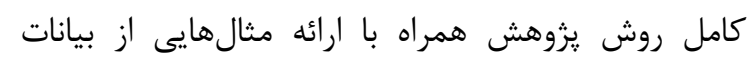

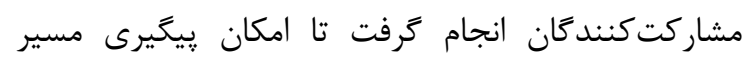

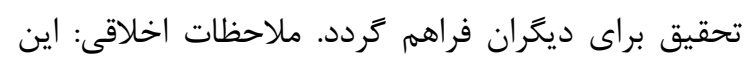

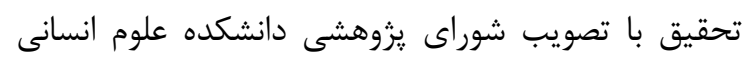

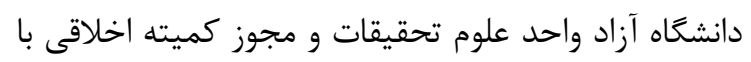

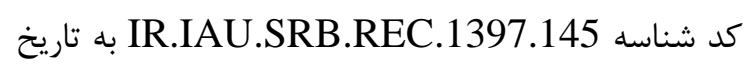

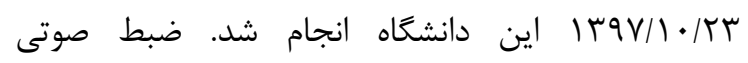
مصاحبهها با كسب اجازه از بيماران تحقق يافت و به آنهاه آنها اطمينان داده شد كه اطلاعات فردى محرمانه خواهد ماند.

\section{بافتهها}

مشاركت كنندكان متشكل از IV بيمار ماستكتومى شده

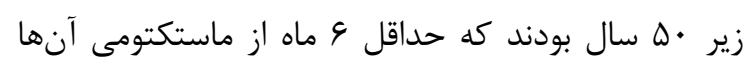

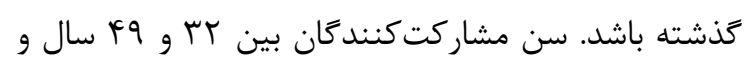

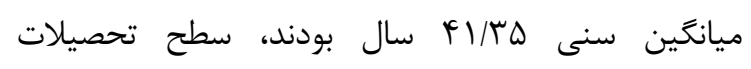

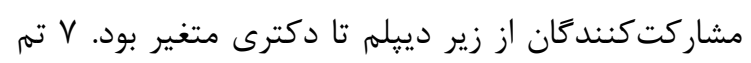
اصلى و \| طبقه حاصل شد (جدول () ).

\section{تم اول؛ زندَى اجتماعى}

اين تم شامل سه طبقه با عناوين: كاهش رفت و آمدها،

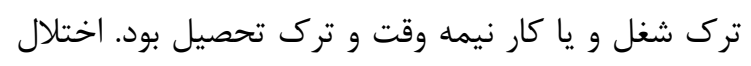

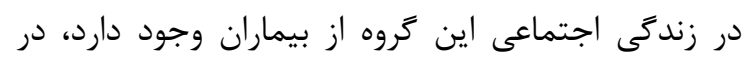

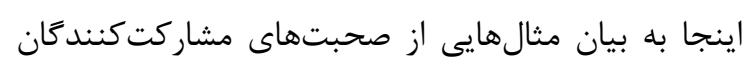
مىيردازيم:

كاهش رفت و آمدها: جون به فاميل نكفته بوديم، تا يكى

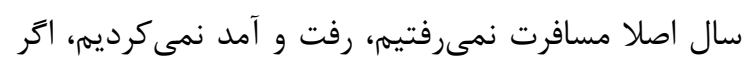

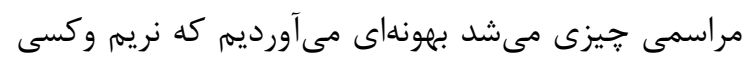

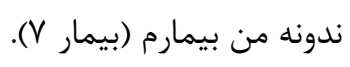

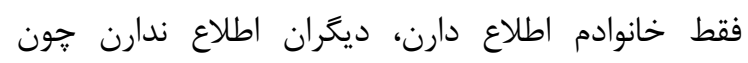

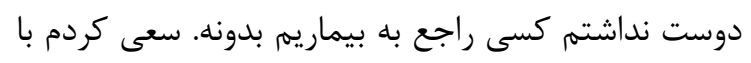

و سيس ساير مشاركت كنند كان هريك ديخرى را معرفى

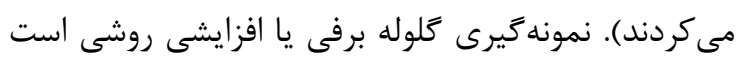

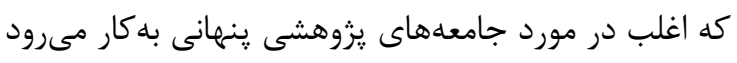

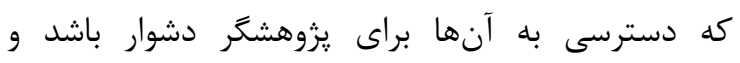

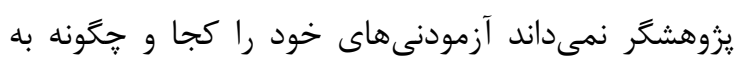
دست بياورد لذا با معدود آزمودنىها (مشاركت كنند أندان)

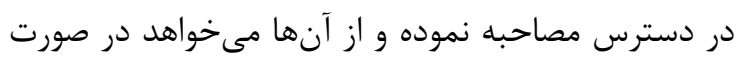

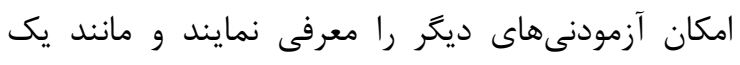

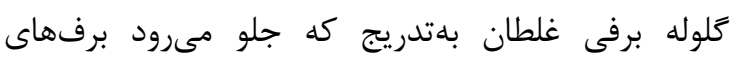

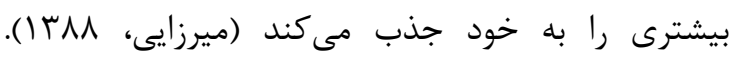

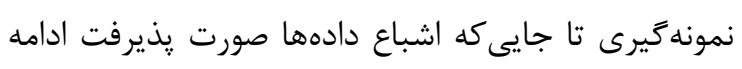

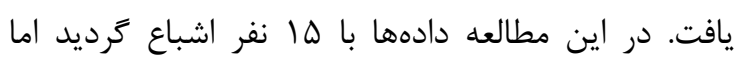

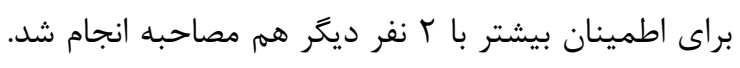

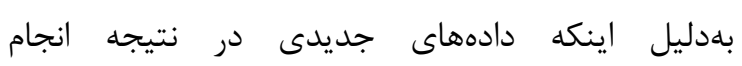

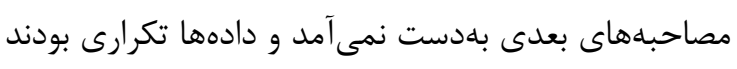
لذا با انجام IV مصاحبه يزوهشكر به به اشباع دادها بها رسيد.

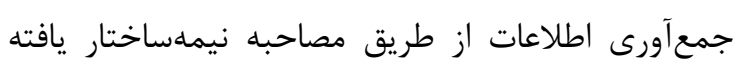

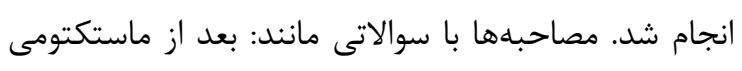

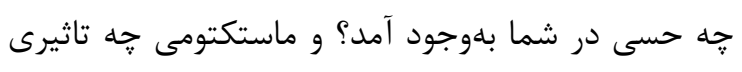

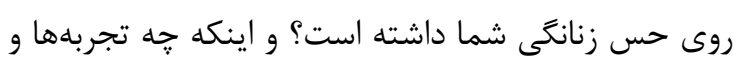

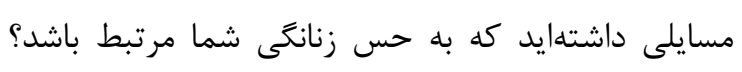

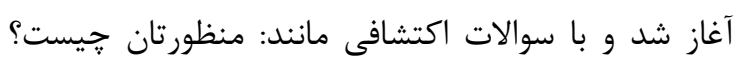

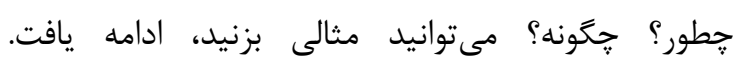

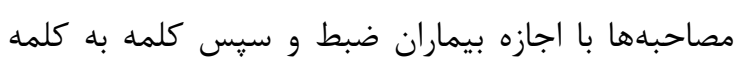

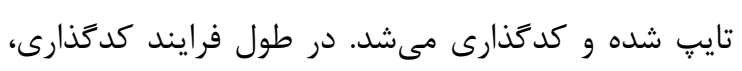

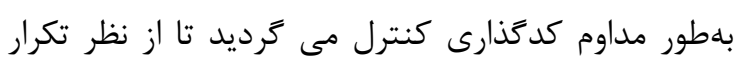

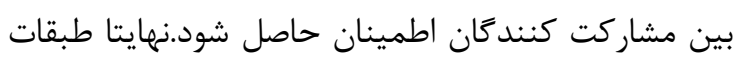

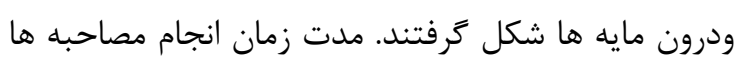

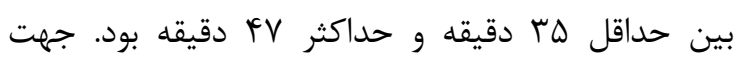

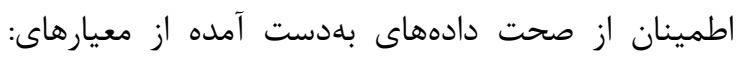

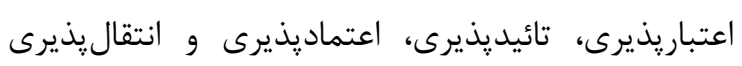

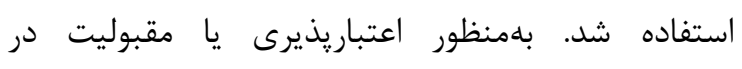

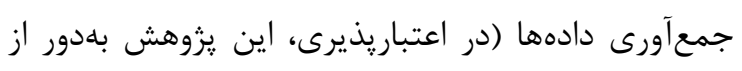

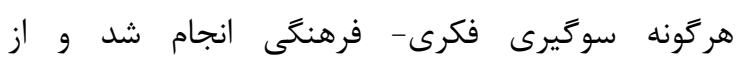

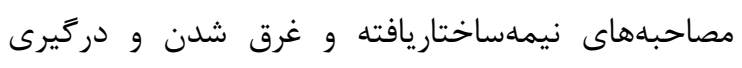

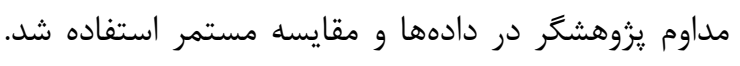

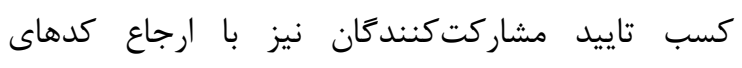
استخراج شده به مشاركت كنندكان حاصل شد مصاحبه مانها

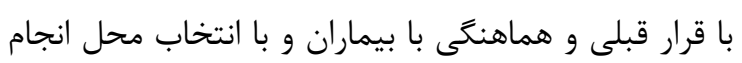




\section{تم دوم؛ تصوير بدنى}

شامل سه طبقه؛ نامتقارن شدن، جذاب نبودن و نياز به به ترميم عضو مىباشد. تصوير بدنى در اكثر بيماران

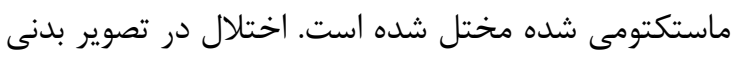
رفته رفته عادى مى شود. بهعنوان مثال:

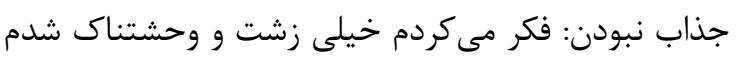
و قابل تحمل نيستم، فكر مى كردم ديگه دوست داشتنى

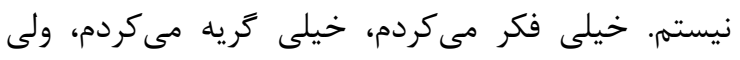
حالا سعى مى كنهم كمتر بهش فكر كنم (بيمارها ) . نامتقارن شدن: خيلى حس بدى بود كه خودمو تو آينه

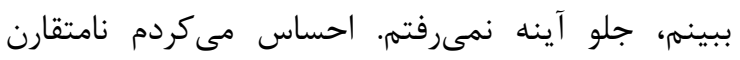
شدم، خودمو مثل زن قبل ارزيابى نمى كردم. به هرحال احساس نقص عضو هميشه با من همراه هست اوايل خيلى بيشتر و حالا كمتر (بيمار ب).

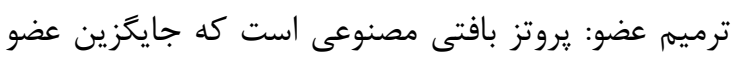
برداشته شده مىشود و فاقد نيِل (نوك يستان) و و آرئول (هاله اطراف نيِل) مىباشد. اكثر بيماران مايلند در صورت امكان از يروتز استفاده كنند. بهعنوان مثال: نياز به ترميم عضو؛ دكتر براى من همون موقع كه اسنهان

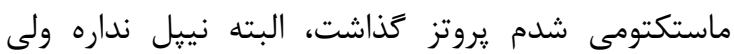

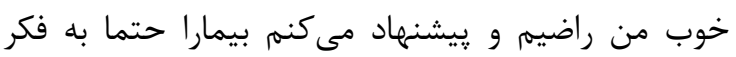

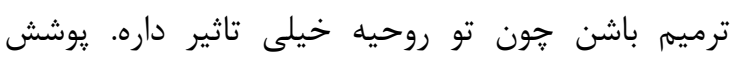
بيمهاى نداره ولى اميدوارم يوشش بيمهاى بيد بيدا بكنه

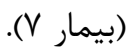

يروتزيكه حذاشتم سنگين بود، اوايل احساسش مى كردم.

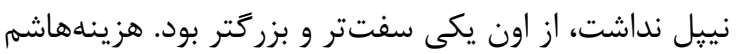
كه خيلى بالاست نميشه ترميمش كرد. يوشش بيمهاى هم نداره. البته من : يروتز و بيشتر از سينه خودم دوس بله

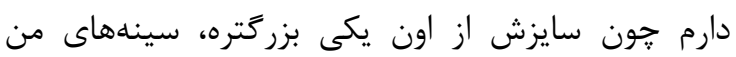

$$
\text { خيلى كوجيك بودن (مى خندد) (بيمار ه ^). }
$$

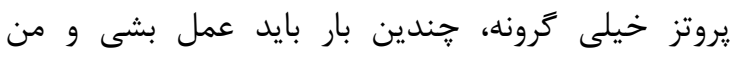

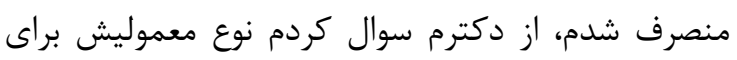

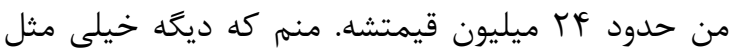

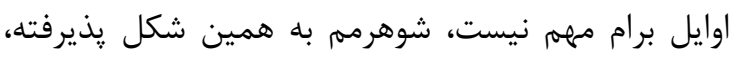

$$
\text { بخاطر همين دنبالش نرفتمم (بيمار • (1). }
$$

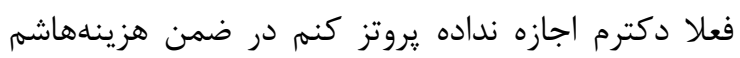
بالاست و بيمههام قبول نمى كنن. من هنوزم مراحل

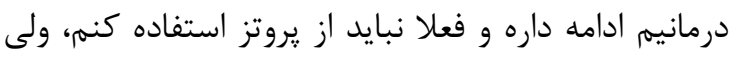

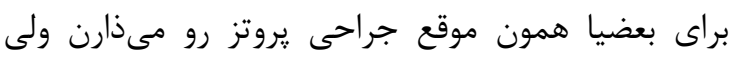

كسى در ارتباط نباشم كه يى ببره. طورى رفتار مى كردم

\begin{tabular}{|c|c|}
\hline طبقات & تمها \\
\hline 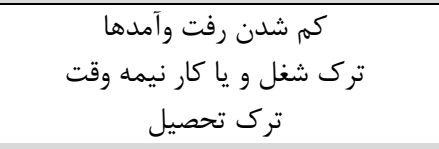 & زندگى اجتماعى \\
\hline نامتار نبارن شدن & تصوير بدنى \\
\hline شكايت از نحاهها وكنجكاوى ديكران & تصور ديگران \\
\hline 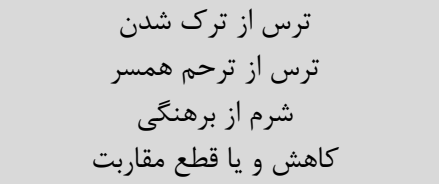 & روابط زناشويى \\
\hline يائسگى زودرس احتمالى & سلامت بارورى \\
\hline شركت در كلاسها و همايشهاى خيريه & ادراك حمايت \\
\hline ناتوانى درانجام كارهاى دستى خدانى خانكى & ايفاى وظايف خانغى \\
\hline
\end{tabular}
كه متوجه نشن (بيمار ك (1).

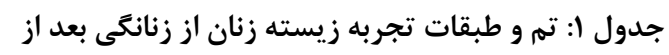

ترك شغل: قبلا تو آموزش و يرورش شاغل بودم ولى الان

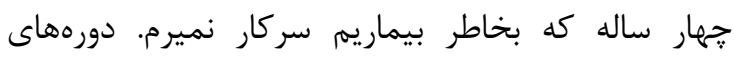

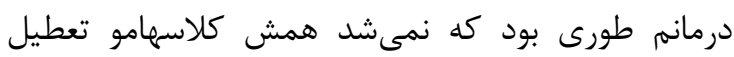

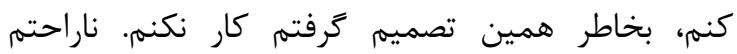

نيستم، به هر حال سلامتى برام مهمهتره (بيمار سار).

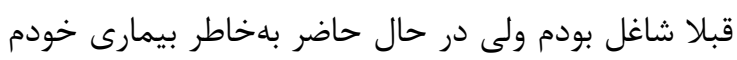
و همزمان بيمارى مادرم كار نمى كنم، يعنى نيمه وقت كار بار بار

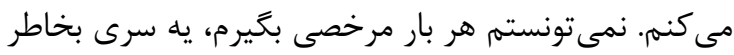

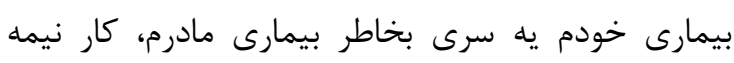
وقت با شرايط من بهتره برام (بيمار كاري (I).

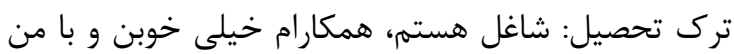

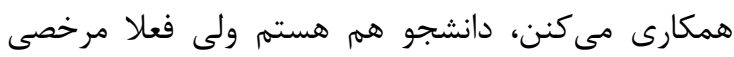

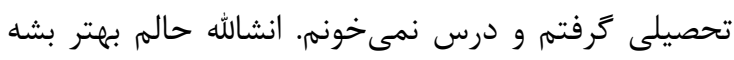
حتما درسمو تموم مى كنم (بيمار له (1). 
تم جهارم؛ روابط زناشويى

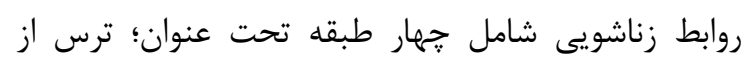

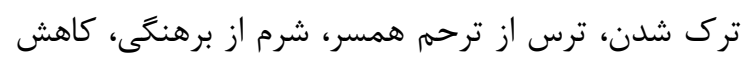

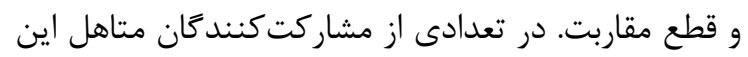

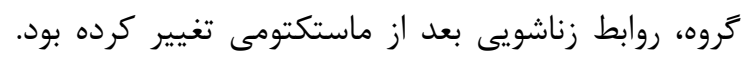

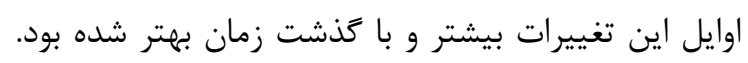
به عنوان مثال: يكى دو سال اول اذيت بودم از نظر رابطه با همسرم، تمايل

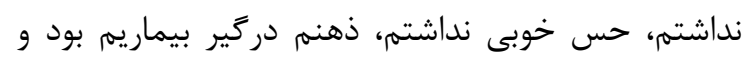

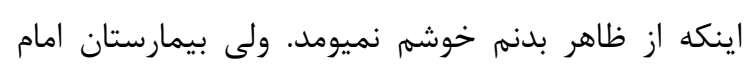

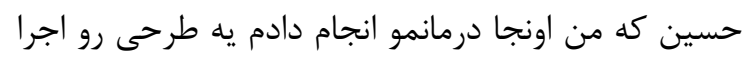

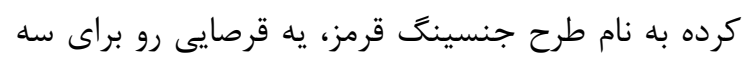

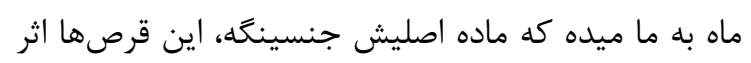

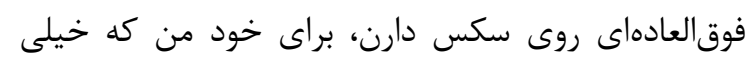

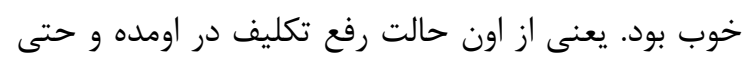

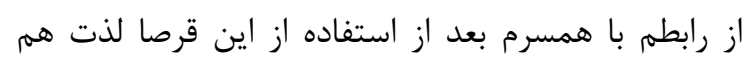

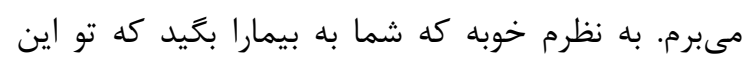
طرح شركت كنن، واقعا تاثير كذاره (بيمار ؟).

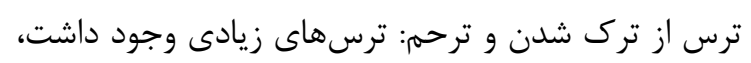

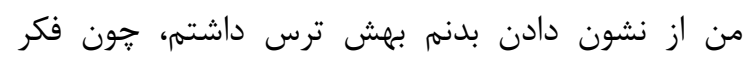

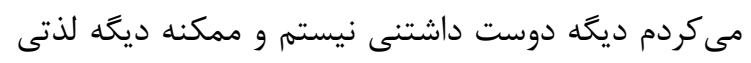

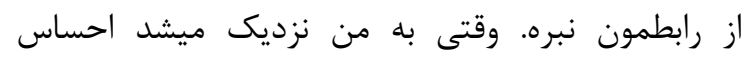

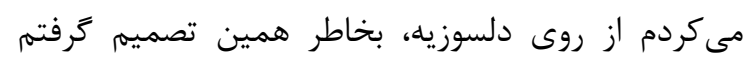

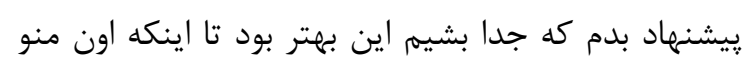

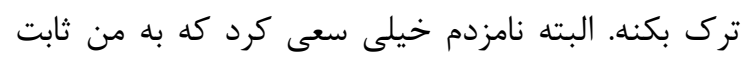

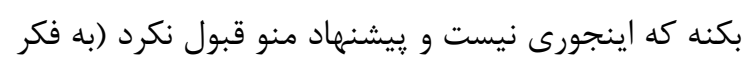

$$
\text { فرو مىرود) (بيمار ها. }
$$

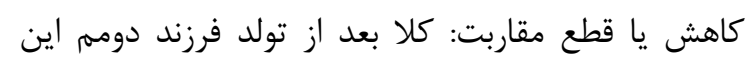

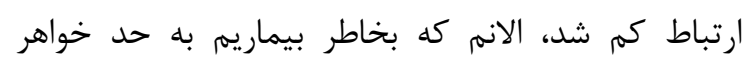

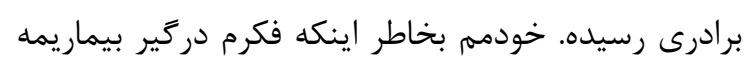

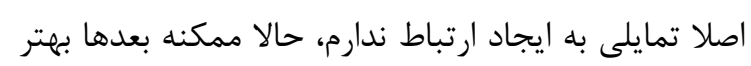

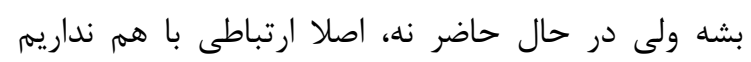

شرم از برهنكى: اوايلش سخت بود برام رابطه داشتن،

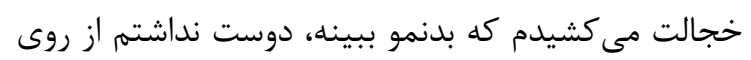

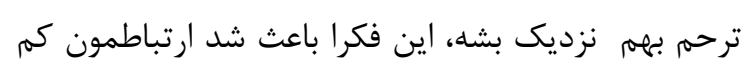

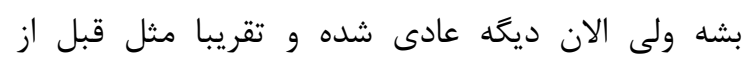

$$
\text { بيماريمه (بيمار • (1). }
$$

براى من اين كارو نكردن، دكترم صلاح ندونست. البته

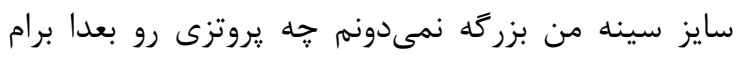

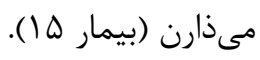

\section{تم سوم؛ تصور ديكران}

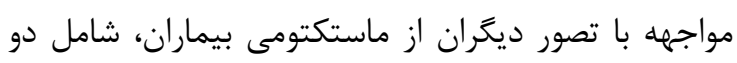

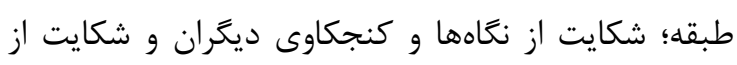

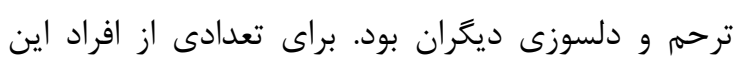

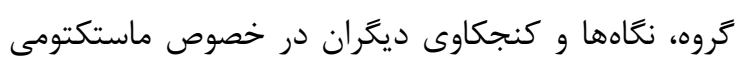

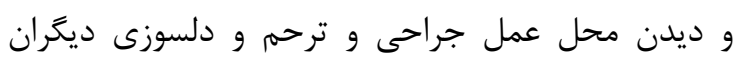
آزاردهنده بود. بهعنوان مثال: شكايت از نكاهها و كنجكاوى ديكران: از اينكه مثل يه يه بهان:

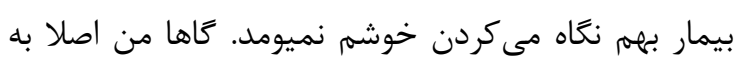

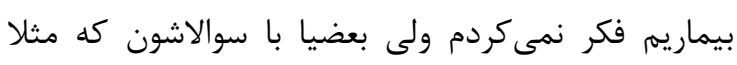

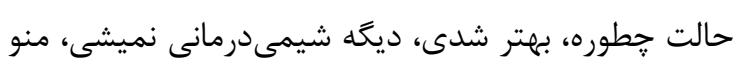

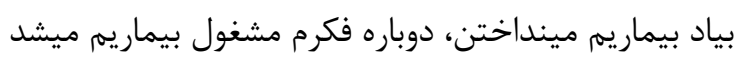
دوباره ناراحت ميشدم، ديكران طورى رفتار مى كردن كه دئن

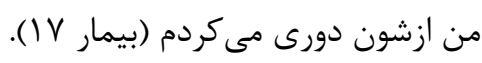

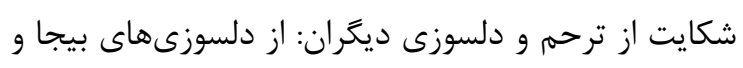

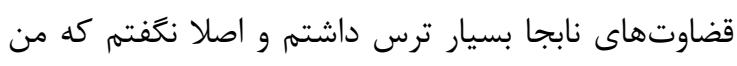

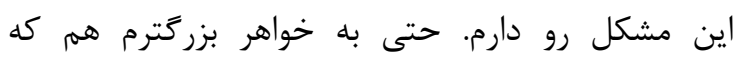

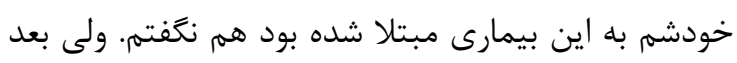

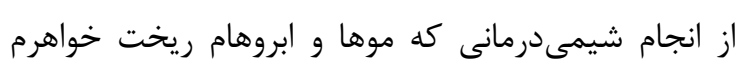

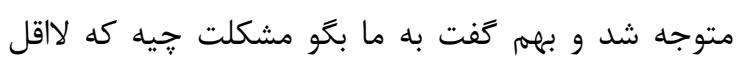

$$
\text { كمكت كنيم (بيمار r) }
$$

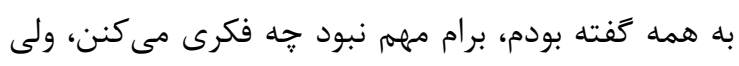

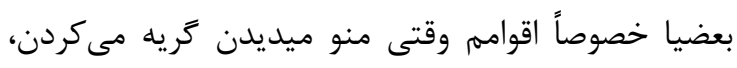

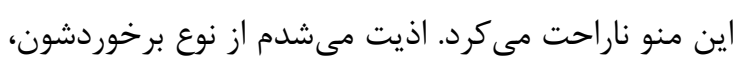

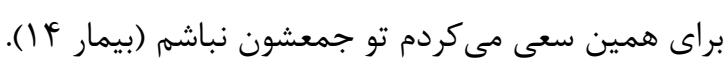

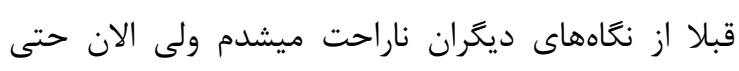

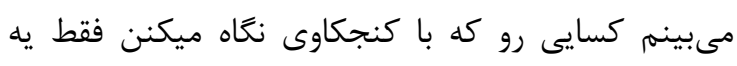

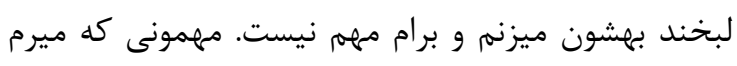

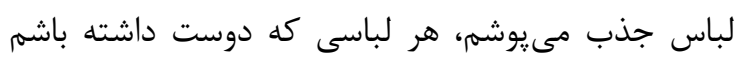

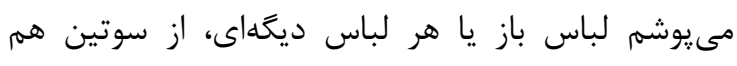

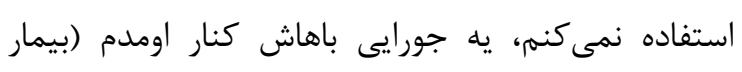




\section{تم ششم؛ ادراك حمايت}

شامل دو طبقه بود؛ شركت دركلاسها و همايشهاى

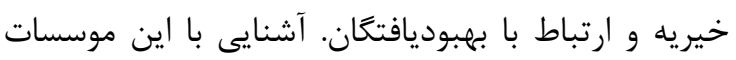

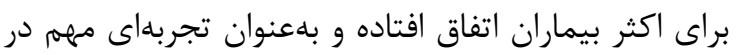

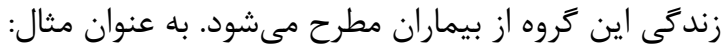
شركت در كلاسها و همايشهاى خيريه: دكترم يك مركز خيريه به من معرفى كرد براى كمك روحى، اونجا با با مراكز

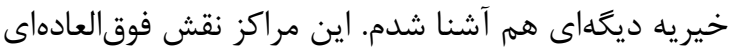
در بهبود شرايط روحى و بيمارى من داشت. طرز فكرم

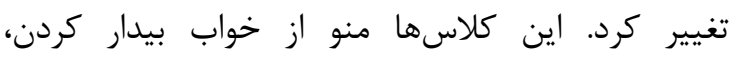
طورى كه فكر مى كنم اين بيمارى يه موهبت المىى بود تو آن زندگى من (خوشحال است) (بيمار ك).

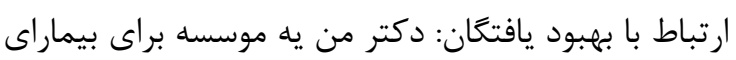

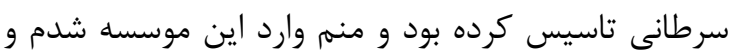
شروع به فعاليت كردم. اوايل ماهى دو سه بار مىرفتم ولى لى

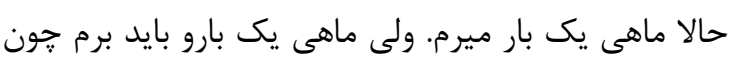

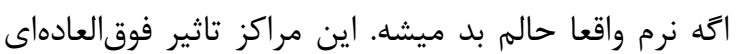
روى روحيه افراد داره، مخصوصا كه ارتباط با بهببود يافتكان خيلى موثره (با انرزى و بكو بخند) (بيمار ).

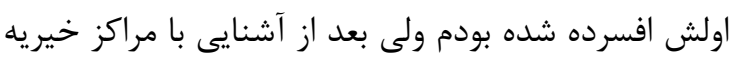
و شركت در كلاساشون طرز فكرم تغيير كرد. قبل بيمارى افكارم يراكنده بود، ولى حالا مسير خاصى يَيدا كرده،

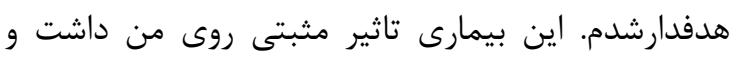

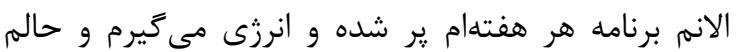
خيلى بهتر ميشه. مثلا ضرب زدن رو خيلى دوس دارم و هرو

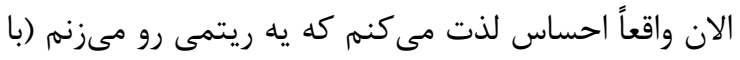
حال روحى عالى) (بيمار • (1).

\section{تم هفتم؛ ايفاى وظايف خانكى}

ايفاى وظايف خانكى شامل دو طبقه؛ ناتوانى در كدبانوگرى و ناتوانى در انجام كارهاى دستى، درتعدادى از بيماران تحت تاثير قراركرفته است. بهعنوان مثال: ناتوانى در كدبانوكرى: از وقتى عمل كردم احساس از كار افتادگى مى كنم يعنى حتى نمى تونم يه جارو برقى بكشمه.

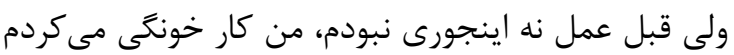

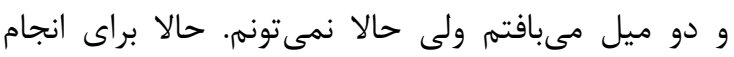

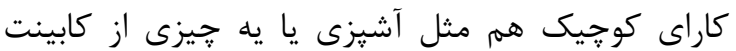

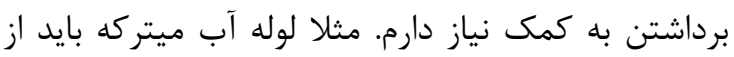

بعد از بيمارى كه ماستكتومى شدم خودم حس خيلى بدى داشتم كه منو ببينه، خيلى بىميل شده بودم. هرجند

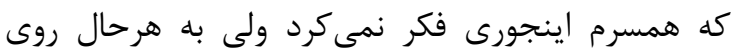

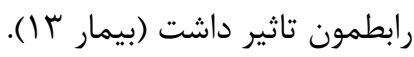

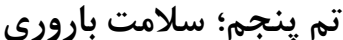
شامل دو طبقه بود؛ يائسگى زودرس و نازايى احتمالى.

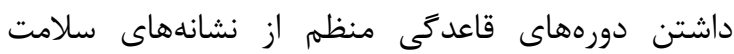

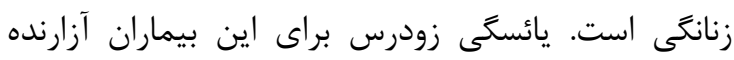

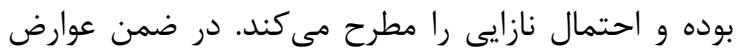

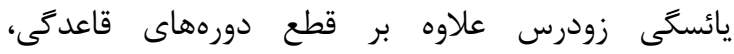

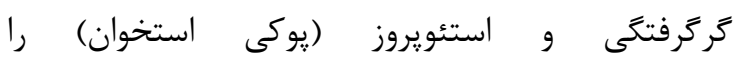
نيز به همراه خواهد داشت. نمونههايى از صحبتهائ مشاركت كنندكان به اين شرح مى باشد:

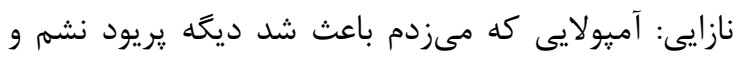

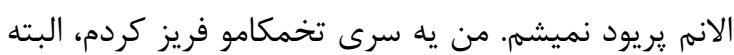
دكترم بازم بهم بيشنهاد كرد كه تخمك فريز كنم. اين

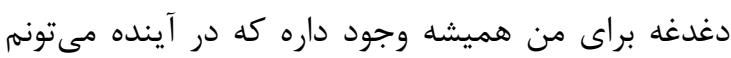
بجهدار بشم يا نه (نكران و ناميد) (بيمار ها.

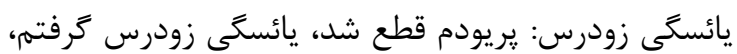

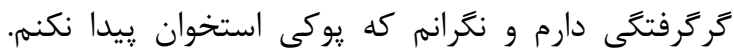

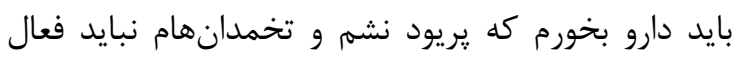

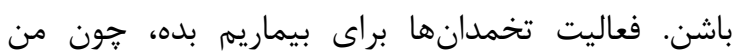
هورمون مثبت هستم، يعنى با تغييرات هورمونى بيماريمم بدتر ميشه (با جهرهاى نكران) (بيمار 9).

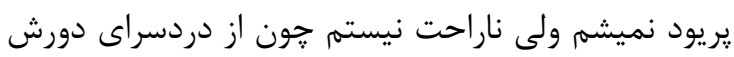

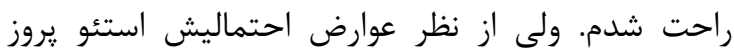
نكرانم و همينكه گركرفتتى داره اذيتم مى كنه. البته

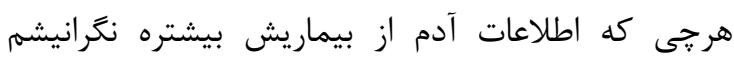
بيشتره، كاهى با خودم ميكم خوش بهحال اونايى كه خيلى اطلاعاتى راجع به بيماريشون ندارن، همش نكرانم

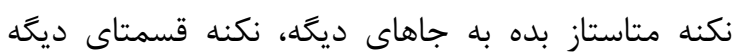
بدنمو در گير كنه (جهره بيمار نكران است) (بيمار 9). 
اين يزوهش زندگى اجتماعى شامل؛ كاهش رفت و آمدها،

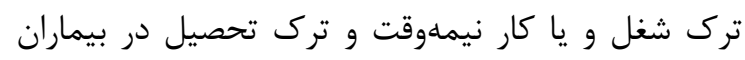

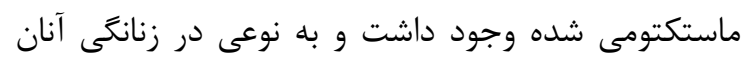

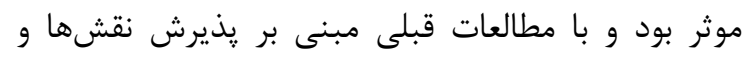

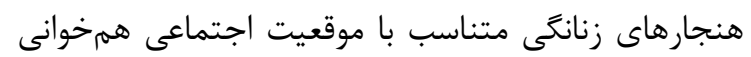

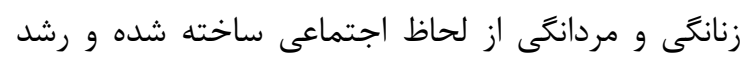

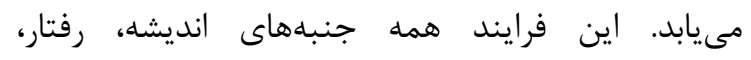

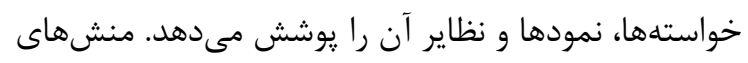

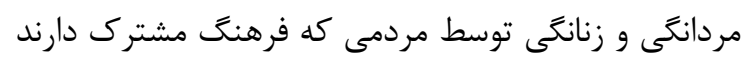

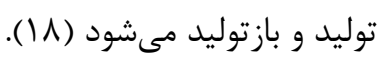

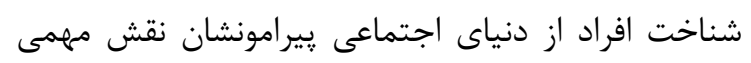

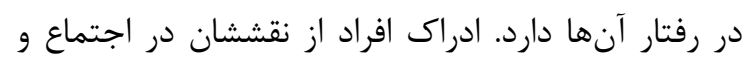

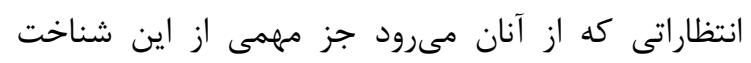

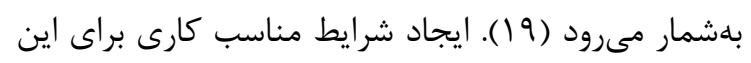

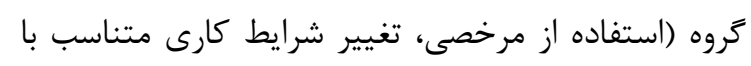

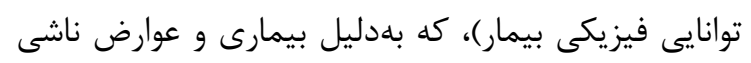

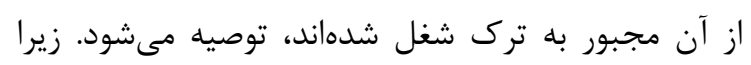

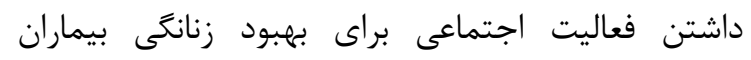
موثراست.
همسايهها كمك بحيرم. از نظر جسمى توانايى قبل رو

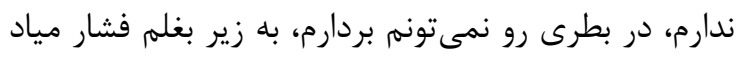

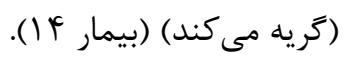

ناتوانى در انجام كارهاى دستى: من من قبمار

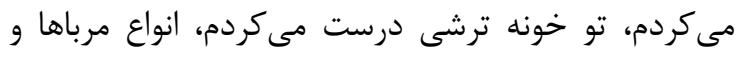

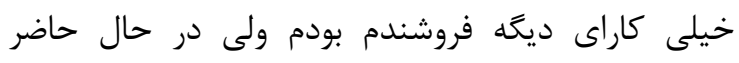

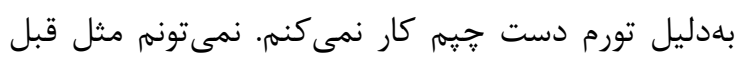

$$
\text { باشم (غمخين مىشود) (بيمار \&). }
$$

بر اساس نتايج اين مطالعه، بلنظر مىرسد زنانكَى در زنان

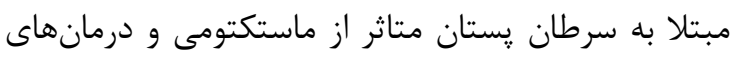

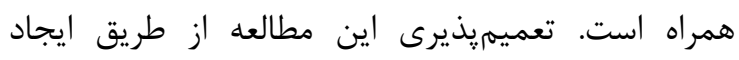

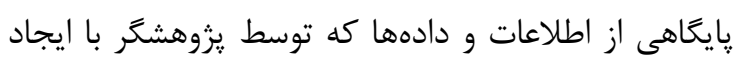
مقولهبندى ماى دقيق انجام شده است بر اساس ويزّكى إنهاى

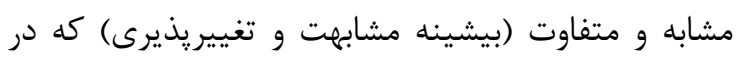

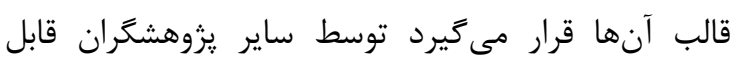

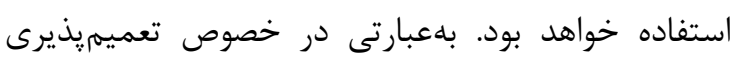

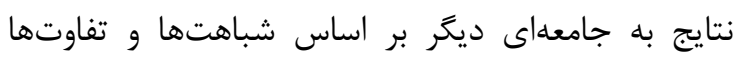
تصميهز كيرى مىشود.

\begin{tabular}{|c|c|c|c|c|c|}
\hline مدت زمان كَذشته & تعداد فرزند & وضعيت تاهل & ميزان تحصيلات & سن & ن \\
\hline يك سال & يك & مطلقه & دييلم & rᄉ & بيمار 1 \\
\hline ينج سال & يكى & متاهل & ليسانس & $i \Delta$ & بيمار r \\
\hline جهار سال & يكى & متاهل & فوق دييلم & $4 q$ & بيمار r \\
\hline ده سال & جهار & بيوه & سيكل & $i \wedge$ & بيمار F \\
\hline يك سال و نيم & ندارد & متاهل & فوق ليسانس & rr & بيمار هـ \\
\hline يك سال & 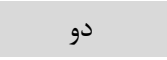 & بيوه & ديِهم & pq & بيمار \\
\hline دوازده سال & 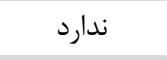 & مجرد & ديڤهم & rv & بيمار V \\
\hline سه سال & ندارد & مجرد & فوق ليسانس & rF & بيمار 1 \\
\hline ده ماه & 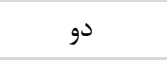 & متاهل & فوق تخصص & rq & بيمار 9 \\
\hline سه سال & 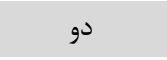 & 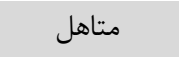 & ديِلم & ff & بيمار +1 \\
\hline يك سال & 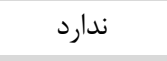 & مجرد & فوق ليسانس & rt & بيمار II \\
\hline دوسال & 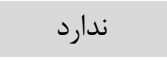 & مجرد & فوق ديِلم & pr & بيمار \\
\hline جهار سال & يك & 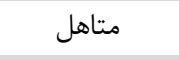 & دكترا & qu & بيمار rا \\
\hline سه سال & 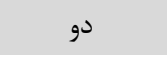 & مطلقه & دييلم & i^ & بيمار IF \\
\hline يك سال & 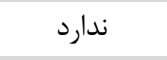 & مجرد & ل ليسانس & fy & بيمار ه1 \\
\hline سه سال & ن & مجرد & ل ليسانس & ro & بيمار 19 \\
\hline جهار سال & دو & متاهل & دييلهم & qu & بيمار IV \\
\hline
\end{tabular}

جدول r: مشخصات فردى مشاركت كنندكان 
حمايت، انجام اقدامات توانبخشى، مشاوره و يِيخيرى است

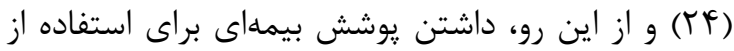

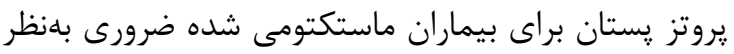
مى مسد. تصورديخران؛ شكايت از نكاهها و كنجكاوى ديكران و شكايت از احساس ترحم ديخران، در اين مطالعه بيانكر

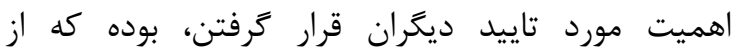
جنبههاى ديخر زنانكى مطرح مىشود. در مطالعات ديخر

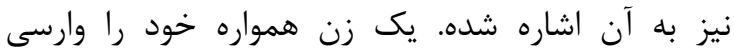

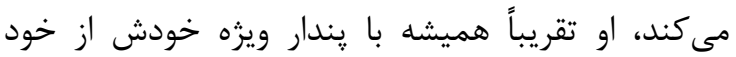

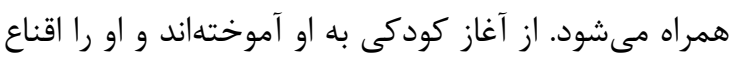
كردهاند تا خودش را به كونهاى مستمر مورد بررسى قرار دهد. براى اينكه קكَونه در حضور مردان ظاهر شود (19). اهميت توجه به نقطه نظر ديكران نسبت به خود درد درد شكلَيرى هويت توسط دختران، تداعى

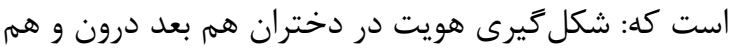

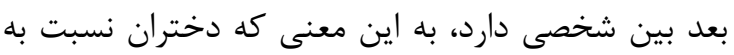

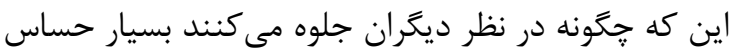

هستند (T) (T).

در مطالعه حاضر روابط زناشويى شامل؛ ترس از ترك

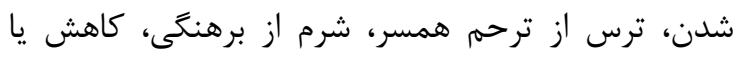

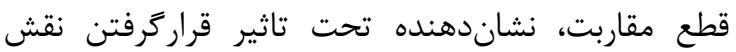
همسرى بيماران است كه به نوعى زندگى زناشويى رانيان

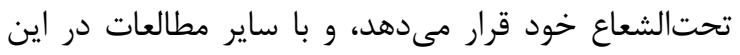
خصوص نيز هم راستا است. از نظر مازلو انسان هيج وقت در رضايت كامل قرار نمى گيرد. رضايت در فرد نسبى است و به محض آنس آنكه

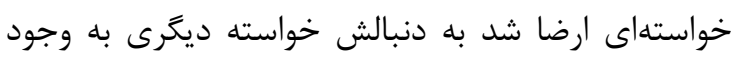

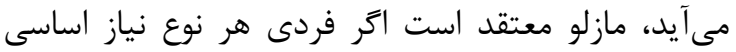
ديكر به هر مفهوم فعال و مزمن داشته باشد، صرفا انسانى لهى

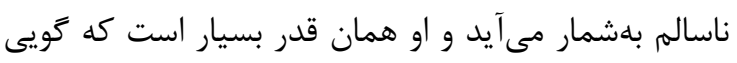

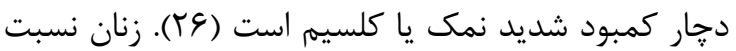
به از دست دادن يستان و عدم يذيرش از سوى مردان دجار استرس و نكرانى هستند (TV)

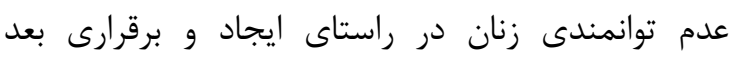
جنسى زندگى قطعا بر زندگى زناشويى تاثير كذاشته و

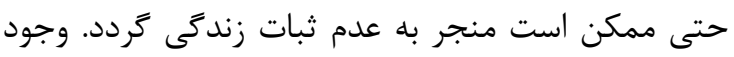

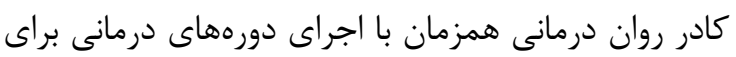

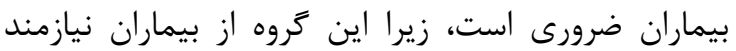

بر اساس مطالعه حاضر تصوير بدنى شامل؛ نامتقارن شدن،

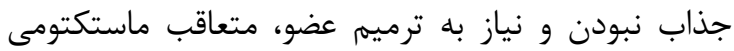

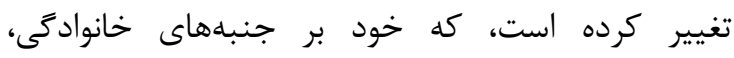
اجتماعى و جنسى تاثير گذار است و با مطالعات انجام شده در اين زمينه همسو مىباشد. زنان با توجه به از دست دادن يستان خود از بدن خود

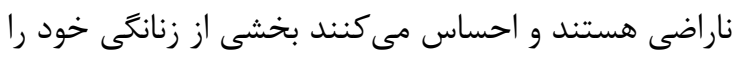

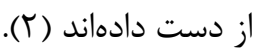
بيمار يس از ماستكتومى شرايطى همانند قطع يك عضو از

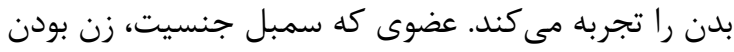

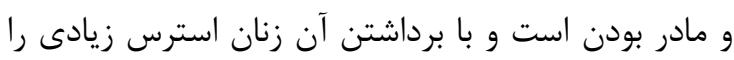
متحمل شده و احتمالا دجار اختلالات خلقى مانق ماند افسردگى و اضطراب و كاهش كيفيت زندگى مى مَردند

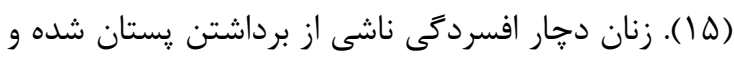

به سختى با اين مشكل كنار آمدهاند (ه). بهعقيده گيدنز، جنسيت بلهعنوان تجربه زيسته افراد

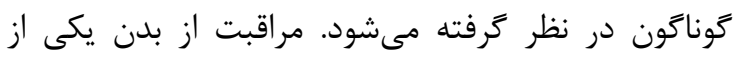
ابزارهاى اساسى است كه شخص به كمك آن روايت معينى از هويت شخصى را محفوظ مىدارد و در عين حال

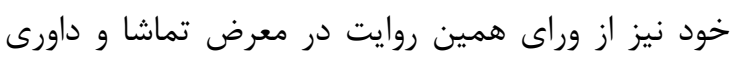
قرار مى خيرد (1) (1). اخرجه تصوير ذهنى از بدن ساختارى خهند بعدى دارد ولى اغلب بهصورت درجهاى از رضايت از ظاهر فيزيكى (اندازه،

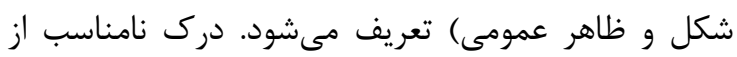
تصوير بدنى و عدم رضايت از آن مىتواند به مشكلات جسمى و روحى منجر شود. تصوير بدنى نه تنها درك

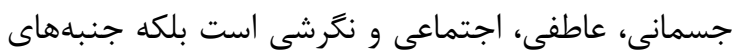

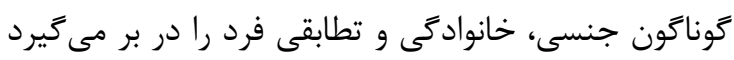

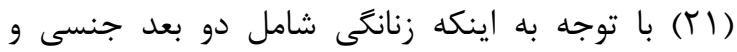
جنسيتى مىباشد (YT)، لذا تغيير در تصوير بدنى بر النى

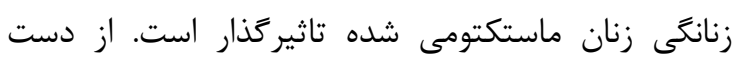
دادن بستان يكى از تغييراتى است كه براى بيمار مشكلات

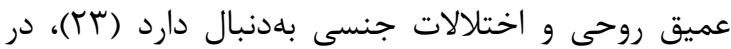

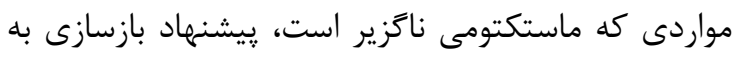

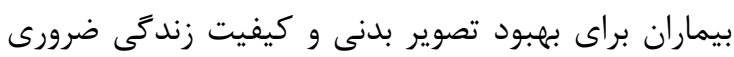
است (9). بهدنبال سرطان يستان و ماستكتومى تصوير ذهنى زنان از خود و هويت زنانكَى آنها مختل مى مشود كه

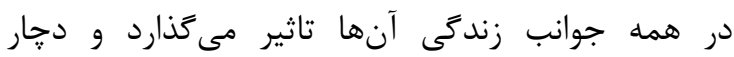
مشكلات خانوادىى مىشوند كه براى بازسازى آن نيازمند 
ايفاى وظايف خانكى نيز كه شامل؛ ناتوانى دركدبانوكرى و

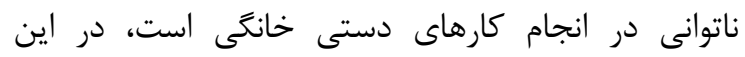

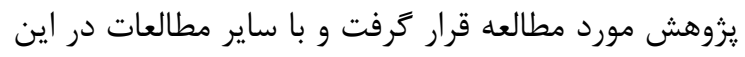

زمينه، همم راستا بود.

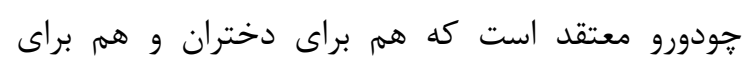

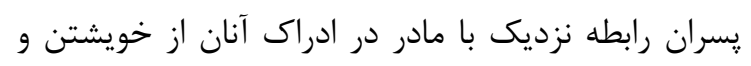

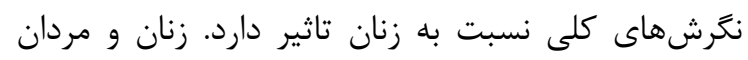

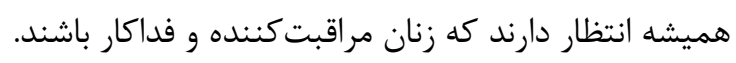
با توجه به نظريه يادگيرى اجتماعى (آلبرت بندورا)، مادر

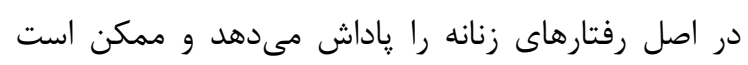

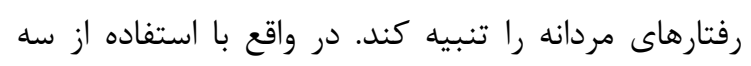
مفهوم تقويت، تقليد و يادگيرى مشاهدهاى، رفتارهاى زنانه

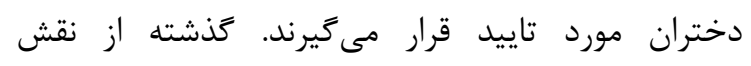

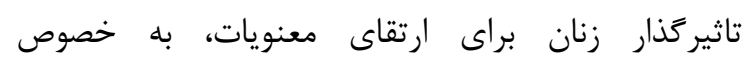

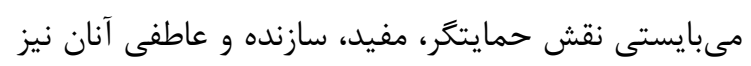

$$
\text { مد نظر قرار كيرد (9) (Y). }
$$

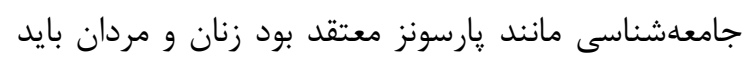

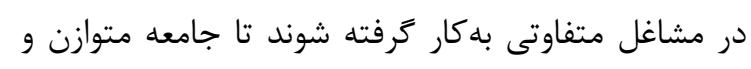

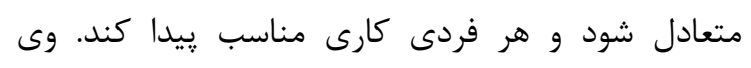

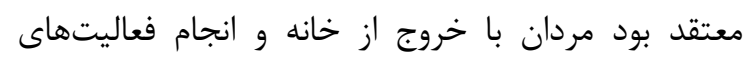

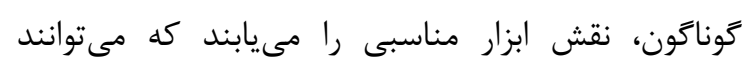

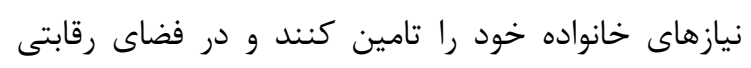

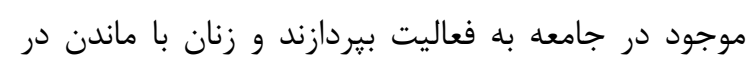

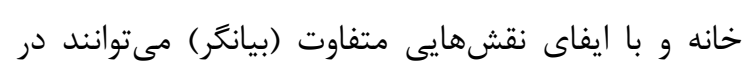
حفظ و بقاى خانواده موثر واقع شوند. در نهايت بلهدليل

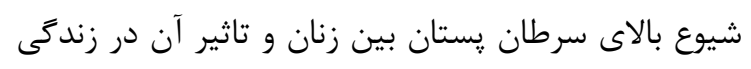

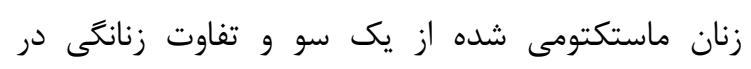
فرهنگها و قوميتهاى مختلف از سوى دينكر، انجام

مطالعات بيشتر در اين زمينه ضرورى بلنظر مى فرسد.

\section{نتيجه كيرى}

بر اساس يافتههاى مطالعه حاضر مىتوان نتيجه كرفت

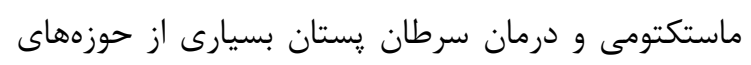

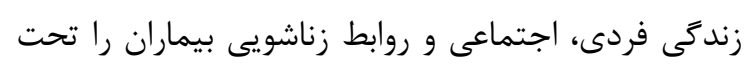

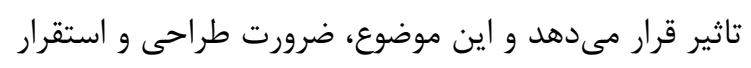

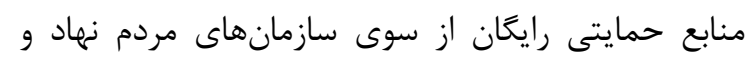

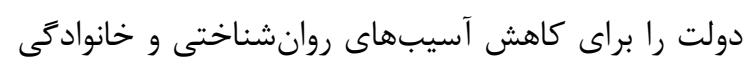
ناشى از اين بيمارى برجسته مي كاهن آسيبها روان.
حمايت روحى مىباشند. بلهور همزمان، برَزارى جلسات مشاوره با خانواده بيمار نيز الزامى است.

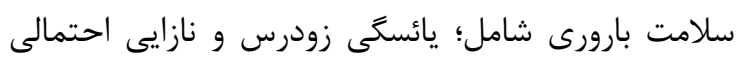

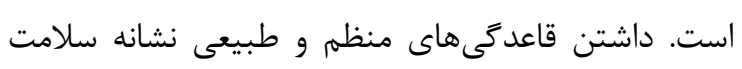

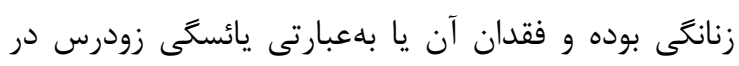

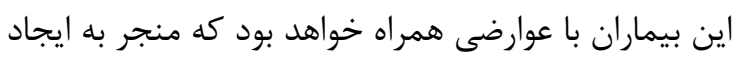

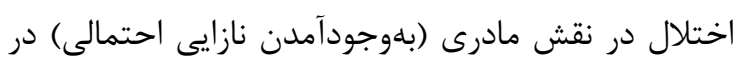

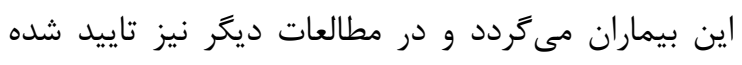

انتظار هر زن از خود اين است كه روزى نقش مادرى را

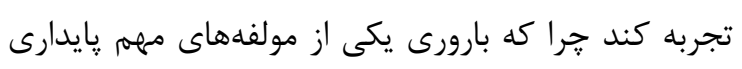

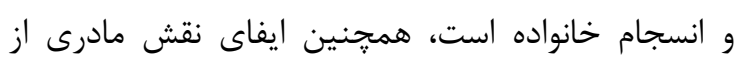

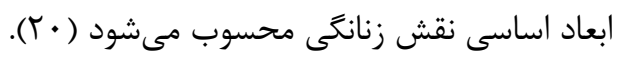

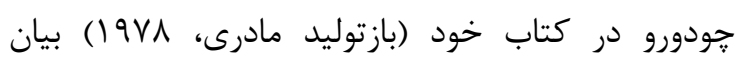

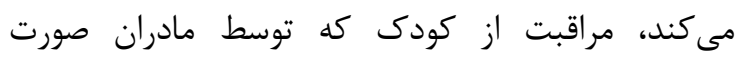

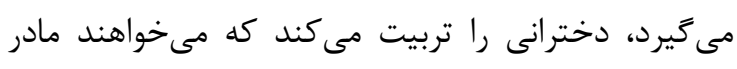

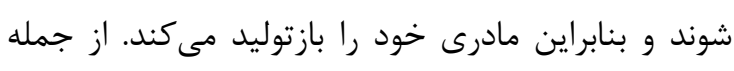
عواملى كه ساختار روانى بين فردى شخص رائ را به به شدت

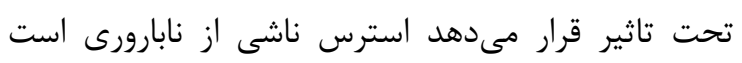

در اغلب جوامع نقش مادرى بهعنوان مهمترين نقش و به

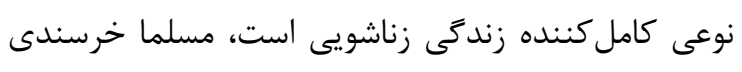

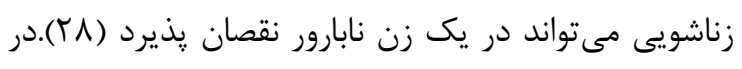

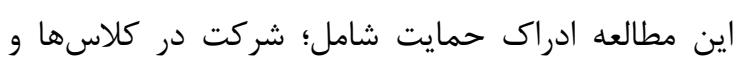

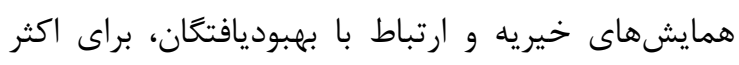
بيماران از طريق يزشك معالج و يا دوستان اتفاق افتاده

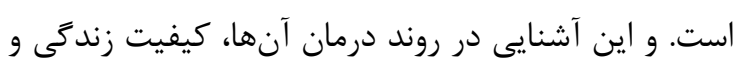

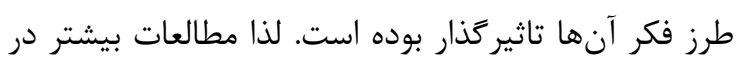

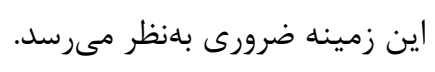

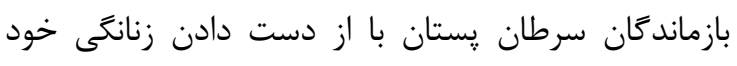

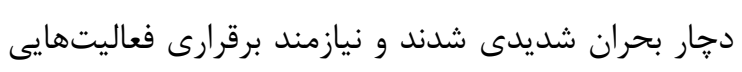

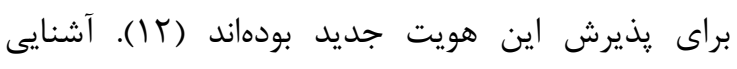

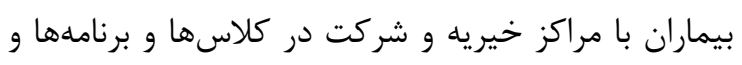

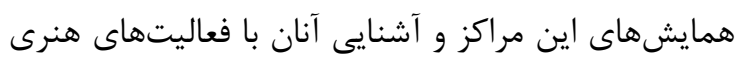

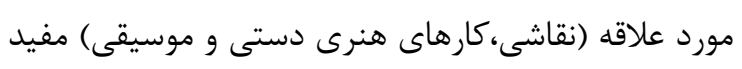

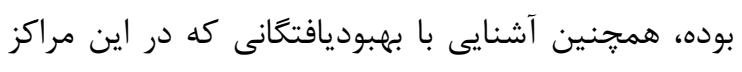

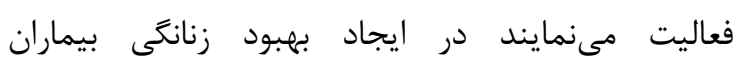
ماستكتومى شده، كمك كننده است. 


$$
\text { مطالعه حاضر وجان اعلام مىدارند كه هيج كونه تعارض منافعى در }
$$

\section{References}

1. Heidari M, Ghodosi M, Naseh AL, Sheikhi R. The relation between hapeness and mental health among women with breast cancer after Mastectomy ,Health and care journal. 2016; 17(1):80-110.

2. Fotios A. Mastectomy.Encyclopedia of quality of life and Well-being research.World journal of surgical oncology. 2014; 13(2):3852-55.

3. Zokaei M, Gharakhani M. Young girls and the experience of femininity, women's research quarterly. 2008; 5(1):200-20.

4. Giddens,A,renewal and recognition:society and personal identity in new era,translated by Movafaghian,N.Tehran,Nai publication. 2007; 10(5):850-78.

5. Burr T. Gender and social psychology, London, Rotledge. 2002; 8(4):22-56.

6. Gharakhani M. Young girls and femininity's values ,Cultural studies and relations journal. 2008; 3(9):100-12.

7. Taleghani F, Parsa.Yekta Z, Nikbakht A. Confronting breast cancer in women with new diagnosis,psychiatry and clinical psychology journal in Iran. 2007; 12(3):34-65.

8. Shayan A, Khalili A, Rahnavardi M. The relation of sexual function and mental health of women with breast cancer, scientitic journal of nursing and midwifery college of Hameddan. 2017; 7(4):385-441.

9. Khademi M, Sajadi M. Breast cancer a phenomenological study, Arak Medical Sciences University journal. 2010; 12(1):195211.

10. Teteh DK, Montgomery SB, Monice S, Stiel L, Clark PL, Mitchell E. My crown and glory: Community, identity, culture,and Black women's cocerns risk; Journal Cogent Arts and Humanities. 2017; 4(1):95-112.

11. Notari SC, Notari L, Nicolas Favez N. The protective effect of asatisfying romantic relationship on Women's body image after breast cancer :alongitudinal study. 2017; 9(2):101-44.

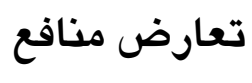

12. Lingshan Sun, Emily Ang. Losing the breast:Ameta-synthesis of the impact in women breast cancer survivors Alice lee centre for Nursing studies, National university of Singapore. 2017; 6(5):32-78.

13. Parton C, Ussher JM, Perz J. The Medical Body:woman's Experiences of sexual Embodiment Across the center Illness trajectory,Women's Reproductive Health. 2017; 4(1):255-331.

14. Matthews H, Semper H. The experiences and challenges of long term breast cancer survivors. 2017; 7(3):276-421.

15. Khezri A, Zare Nezhad H, Hosseinei N. The relationship between sexual right and satisfaction matrimong in addict spouses of Yazd,second international psychology conference,lifestyle and educationalsience, Mashhad, University of Torbat Heidarieh. 2016; 5(8):56-98.

16. Danaei Fard H. Methodology of qualitative research of management,Eshraghi publication. 2011; 9(5):55-93.

17. Berek J. Novak E. Female Genital Disease 15th Ed,Lippincott Williams andWilkins. 2012; 9(4):375-465.

18. Costa PT, Mc Care RR. Normal personslity assessment inclincal practice: The NEO personality inventory, psychologyical assessment, jornal of consulting and clinical psychology. 2005; 4(1):5.

19. Iman M, Noshadi M. Analysis of qualitative content, Imam Khomaeini research base and institute. 2012; 3(2):45-57.

20. Abbott P, Wallace C. Women sociology, translated by Najm Araghi.M, Tehran, Ney publication. 2002; 8(6):42-65.

21. Terner J. Creation of sociology theoy, translated by Abdol Ali Lahsaei Zadeh, Shiraz, Navid publication $6^{\text {th }}$ publishment. 2000; 7(3):120-54.

22. Hamzavi Abedi F, Bagherian F, Mazaheri M. Analyze Irenian young women's perception of 
femininity norms, Shenakhte Ejtemaei Journal. 2019; 1(1):230-51.

23. Jessi B. World of women, translated by Shahrzad Zoffan, Tehran, Akhtran. 2006; 885790.

24. Beck P, Wysowski DK, Downey W, ButlerJones D. Stain use and The risk of breast cancer. Jce. 2003; 280:56-85.
Engle j, Kerr j, Schlesinger-Raab A, Sauer H, Holzel D. Quality of Life following breastconserving therapy or mastectomy: Results of a 5-year prospeetive study. Breast j. 2004; 10(3): 223-31.

26. Akbari M. Physical image and self-steem: Iranian breast diseases quartery. 2013; 5(2): 63-85. 